\title{
Molecular mechanisms of inflammation and tissue injury after major trauma-is complement the "bad guy"?
}

\author{
Miriam D Neher ${ }^{1}$, Sebastian Weckbach ${ }^{1}$, Michael A Flierl ${ }^{1}$, Markus S Huber-Lang ${ }^{2}$ and Philip F Stahel ${ }^{1,3^{*}}$
}

\begin{abstract}
Trauma represents the leading cause of death among young people in industrialized countries. Recent clinical and experimental studies have brought increasing evidence for activation of the innate immune system in contributing to the pathogenesis of trauma-induced sequelae and adverse outcome. As the "first line of defense", the complement system represents a potent effector arm of innate immunity, and has been implicated in mediating the early posttraumatic inflammatory response. Despite its generic beneficial functions, including pathogen elimination and immediate response to danger signals, complement activation may exert detrimental effects after trauma, in terms of mounting an "innocent bystander" attack on host tissue. Posttraumatic ischemia/reperfusion injuries represent the classic entity of complement-mediated tissue damage, adding to the "antigenic load" by exacerbation of local and systemic inflammation and release of toxic mediators. These pathophysiological sequelae have been shown to sustain the systemic inflammatory response syndrome after major trauma, and can ultimately contribute to remote organ injury and death. Numerous experimental models have been designed in recent years with the aim of mimicking the inflammatory reaction after trauma and to allow the testing of new pharmacological approaches, including the emergent concept of site-targeted complement inhibition. The present review provides an overview on the current understanding of the cellular and molecular mechanisms of complement activation after major trauma, with an emphasis of emerging therapeutic concepts which may provide the rationale for a "bench-to-bedside" approach in the design of future pharmacological strategies.
\end{abstract}

\section{Introduction}

Despite significant advances in injury prevention, prehospital resuscitation strategies, and modern intensive care, trauma remains the main cause of death in young people in the United States, resulting in more years of potential life lost before the age of 75 years than any other disease [1-4]. Until present, the pathophysiology of major trauma remains poorly understood [5,6]. In principle, the pathophysiological sequelae of major injuries are characterized by the initial traumatic impact (so-called "first hit"), followed by a cascade of subsequent immunological reactions, which render the patient susceptible to a potentially detrimental "second hit" insult [7]. The activation of innate immune response mechanisms has been characterized as a

\footnotetext{
* Correspondence: philip.stahel@dhha.org

'Department of Orthopaedic Surgery, University of Colorado Denver, School of Medicine, Denver Health Medical Center, 777 Bannock Street, Denver, CO 80204, USA

Full list of author information is available at the end of the article
}

crucial event initiating the early phase of hyperinflammation within hours to days after major trauma [6-8]. While innate immunity is classically considered to be the immediate "first line of defense" against non-self antigens (e.g. infectious pathogens), a traumatic insult can induce a similarly potent acute inflammatory response [9-13]. The trauma-induced immune response may be limited locally, as in isolated injuries, or result in a massive systemic immune activation, as in patients with multiple injuries [1]. The endogenous triggers of trauma-associated inflammation have been thoroughly investigated and characterized in recent years $[7,14]$. The so-called "first hit" induced by a traumatic impact leads to the appearance of an arsenal of "damage-associated molecular patterns" (DAMPs) that are recognized by receptors of immune cells [15]. DAMPs represent a recently characterized large superfamily of danger signals which can activate innate immune responses after trauma or trauma-induced complications, such as infection and sepsis $[7,16]$. The DAMP 
family of danger signals includes the so-called "pathogenassociated molecular patterns" (PAMPs) and molecules termed "alarmins" [17]. The list of molecules belonging to the DAMP family has been increasing dramatically in recent years, and their pathophysiological function in mediating trauma-induced inflammation is far from being fully understood [18]. PAMPs represent a heterogenic entity of recently described inflammatory molecules related to the innate immune system $[17,19]$. These microbial molecules are recognized by the immune system as foreign due to their characteristic molecular patterns. In contrast, the so-called "alarmins" represent the correlate of PAMPs for all non-pathogen-derived danger signals which originate from tissue injury [17]. This heterogeneic group of danger molecules is capable of activating innate immune responses in response to tissue damage and cell injury. The alarmins comprise the "heat-shock proteins" (HSPs), annexins, defensins, as well as "classical" markers of tissue injury, such as the S100 protein and the high mobility group box 1 (HMGB1) protein $[17,20]$.
Immunologically competent cells recognize both PAMPs and DAMPs through multiligand receptors expressed on their surfaces, such as Toll-like receptors (TLRs) [21,22].

The very early stage after tissue trauma is characterized by activation of cellular and molecular effectors of the innate immune system, including complement activation and recruitment and activation of neutrophils (polymorphonuclear leukocytes; PMNL) [6,7]. The complement system appears to represent the crucial effector of innate immune responses in the early phase after major trauma [23-25]. Once the cascade is activated through one of three (five) established pathways (Figure 1), complement plays a critical role in the elimination of invading pathogens by opsonization for phagocytosis (C3b, C4b), chemotaxis of leukocytes (C3a, C5a), and by direct lysis of pathogens through the membrane attack complex (MAC, C5b-9) $[23,26,27]$. The generation of anaphylatoxins C3a and C5a provides potent chemoattractants for phagocytes and neutrophils, and recruit these immune cells to the site of injury $[24,28,29]$. The anaphylatoxins further induce

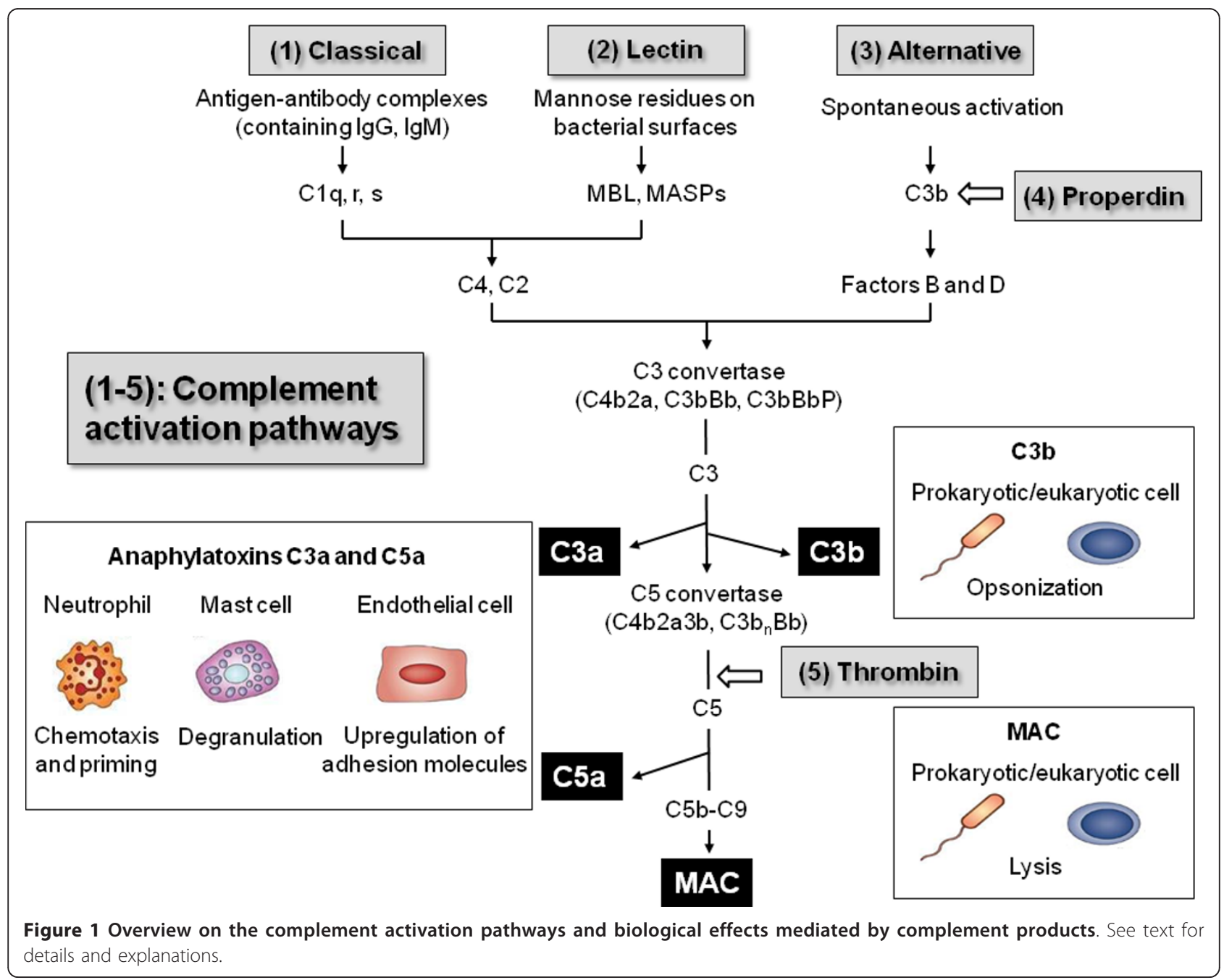


degranulation of mast cells, basophils and eosinophils and mediate the hepatic acute-phase response [30,31]. Finally, the generation of $\mathrm{C} 5 \mathrm{~b}$ by cleavage of $\mathrm{C} 5$ initiates the terminal complement pathway with MAC formation. The $\mathrm{MAC}$ forms through the self-association of $\mathrm{C} 5 \mathrm{~b}$ along with $\mathrm{C} 6$ through $\mathrm{C} 9$ and leads to the formation of a large membranolytic complex capable of lysing prokaryotic and eukaryotic cells [32]. Multiple previous studies have unequivocally shown that trauma activates complement, both locally at the site of injury, and systemically. Early studies in the 1980s revealed that the complement cascade is activated at the level of C3 in serum of trauma patients, and the extent of activation correlates with the severity of injury [33,34].

The neutrophil (or PMNL) has been established as the cellular counterpart to the humoral immune response mediated by complement activation, and represents a "key effector" cell of the early posttraumatic immune response. Within minutes, and up to several days after injury, neutrophils play an important role in mounting the immunological defense and the debridement of injured tissue. Primed neutrophils are capable of mediating an inflammatory response, characterized by release of cytokines, chemokines, reactive oxygen species, and tissue-toxic enzymes, such as myeloperoxidase and elastase $[20,35]$. Aside from the beneficial role of neutrophils in host-defense and clearance of damaged tissue after trauma, excessive priming and cellular PMNL activation may lead to an overwhelming inflammatory response and "innocent bystander" injury to host tissue $[35,36]$. Uninjured tissue may become damaged by the local release of toxic metabolites and enzymes, thus contributing to remote organ injury (e.g. to brain and lungs), by contributing to tissue edema and secondary tissue damage [12,35,37-39].

Based on the delicate balance between protection and harm, the posttraumatic inflammatory response has been rightfully termed a "double-edged sword" [40-42]. The present review will outline the current understanding of complement activation and regulation after major trauma, with a focus on specific injury patterns, including musculoskeletal trauma, ischemia/reperfusion, chest and brain injuries. We will furthermore discuss potential new pharmacological strategies related to the targeted inhibition of complement, which may shed some hope into the design of new immunomodulatory treatment modalities for severely injured patients in the future.

\section{Complement activation and effector functions}

The complement system represents one of the phylogenetically oldest cascade systems of the body, consisting of a proteolytic cascade of more than 30 soluble and surface-bound proteins that can be activated by the classical, the lectin and the alternative pathway $[32,43,44]$.
Recently, two additional complement activation pathways have been described, i.e. the properdin and the thrombin pathways, both of which will be discussed in more detail below. Figure 1 depicts a rough schematic of the so far known complement activation pathways and of the biological functions of activated complement components. In brief, the three main activation pathways converge in the formation of enzymatic complexes termed the C3 convertases and $\mathrm{C} 5$ convertases, which cleave the two main components of the complement system, C3 and C5. The two proteolytic fragments generated by the action of the convertases are the anaphylatoxins C3a and C5a. Both can trigger proinflammatory signaling through binding to their corresponding receptors, the $\mathrm{C} 3 \mathrm{a}$ receptor $(\mathrm{C} 3 \mathrm{aR})$ and $\mathrm{C} 5 \mathrm{a}$ receptor ( $\mathrm{C} 5 \mathrm{aR}$ and $\mathrm{C} 5 \mathrm{~L} 2$ ), on various myeloid and non-myeloid cells $[28,29,45,46]$. C5a is a powerful chemoattractant for neutrophils that recruits immune cells to the site of injury and activates cellular attack mechanisms like oxidative burst and lysosomal enzyme release $[47,48]$. Furthermore, the anaphylatoxins contribute to the degranulation of mast cells and basophils, induce the expression of adhesion molecules on endothelial cells, cause smooth-muscle contraction and enhance the acute phase response of the liver [48]. The cleavage of $\mathrm{C} 3$ by $\mathrm{C} 3$ convertases leads to the generation of a second major fragment, $\mathrm{C} 3 \mathrm{~b}$, which acts as an opsonin facilitating the removal of bacteria and cell detritus by phagocytic cells [49]. Finally, the formation of C5b by cleavage of $\mathrm{C} 5$ initiates the assembly of a multimolecular complex, the MAC (C5b-9), that perforates membranes of bacteria and nucleated cells and causes rapid cell lysis and death $[45,50,51]$.

Recently, a second initiation mechanism of the alternative activation pathway was described, termed the properdin pathway [52]. Properdin is capable of recognizing several DAMPs and PAMPs on foreign and apoptotic cells, thus allowing C3 convertase assembly on the target surface [32,52]. Properdin also functions as a stabilizer for $\mathrm{C} 3$ convertase complexes of the alternative pathway. In addition to properdin, a fifth complement activation pathway has been described, which identified the clotting factor thrombin as a C5 convertase. This notion was supported by the observation that thrombin is capable of generating $\mathrm{C} 5 \mathrm{a}$ in the absence of $\mathrm{C} 3$, thus providing a direct link between the complement and coagulation system $[53,54]$.

\section{Traumatic brain injury}

Traumatic brain injury (TBI) induces a profound inflammatory response that contributes to brain edema, neuronal cell death, and adverse outcome [55-57]. Posttraumatic activation of the complement cascade has been shown to play a pivotal role in the development of secondary brain injury (Table 1) [10,12,23,24,58,59]. Multiple experimental 
Table 1 Insights from experimental complement inhibition based on genetically engineered mice and pharmacological approaches in models of traumatic brain injury (TBI).

\begin{tabular}{|c|c|c|c|c|}
\hline $\begin{array}{l}\text { Complement inhibitor/mouse } \\
\text { strain }\end{array}$ & $\begin{array}{l}\text { Inhibited complement } \\
\text { molecule }\end{array}$ & $\begin{array}{l}\text { Affected complement } \\
\text { pathway }\end{array}$ & Inhibition-induced effects & Reference \\
\hline $\mathrm{C}^{-/-}$mice & C3 & $\begin{array}{l}\text { Classical, alternative, } \\
\text { lectin }\end{array}$ & Reduction of neutrophil extravasation, injury sizes and chemokine expression. & Sewell et al., 2004 [67] \\
\hline $\mathrm{C4}^{-/-}$mice & C4 & Classical, lectin & Decrease of motor deficits and brain lesion size. & You et al., 2007 [81] \\
\hline $\begin{array}{l}\text { Factor } B^{-/-} \text {mice, anti-factor } B \\
\text { monoclonal } A b\end{array}$ & Factor B & Alternative & $\begin{array}{l}\text { Attenuation of cerebral tissue damage and neuronal apoptosis, upregulation } \\
\text { of anti-apoptotic mediators, down-regulation of pro-apoptotic markers. }\end{array}$ & $\begin{array}{l}\text { Leinhase et al., 2006, } \\
2007[79,80]\end{array}$ \\
\hline CD59a $a^{-/}$mice & CD59a & Terminal & $\begin{array}{l}\text { Exacerbated tissue injury in CD59a-deficient mice, implying MAC-mediated } \\
\text { secondary neuronal cell death. }\end{array}$ & Stahel et al., 2009 [88] \\
\hline C1-INH & $\mathrm{C} 1 \mathrm{r} / \mathrm{s}, \mathrm{MASP}, \mathrm{C} 3 \mathrm{~b}$ & Classical & $\begin{array}{l}\text { Reduction of motor deficits, cognitive } \\
\text { dysfunction and contusion volume. }\end{array}$ & Longhi et al., 2009 [59] \\
\hline sCR1 & C3 convertases & $\begin{array}{l}\text { Classical, alternative, } \\
\text { lectin }\end{array}$ & $\begin{array}{l}\text { Reduction of neutrophil accumulation } \\
\text { in the brain. }\end{array}$ & $\begin{array}{l}\text { Kaczorowski et al., } 1995 \\
\text { [68] }\end{array}$ \\
\hline Crry-lg, GFAP-sCrry mice & C3 convertases & $\begin{array}{l}\text { Classical, altenative, } \\
\text { lectin }\end{array}$ & $\begin{array}{l}\text { Neuroprotection with improved neurological scores and decreased tissue injury } \\
\text { and blood-brain barrier dysfunction. }\end{array}$ & $\begin{array}{l}\text { Leinhase et al., } 2006 \\
\text { [71] } \\
\text { Rancan et al., } 2003 \text { [70] }\end{array}$ \\
\hline VCP & $\begin{array}{l}\text { C3b, C4b, C3 } \\
\text { convertases }\end{array}$ & $\begin{array}{l}\text { Classical, alternative, } \\
\text { lectin }\end{array}$ & Improvement of sensorimotor outcome and spatial memory. & $\begin{array}{l}\text { Pillay et al., } 2007 \text { [72] } \\
\text { Hicks et al., } 2002 \text { [69] }\end{array}$ \\
\hline C5aR antagonist & C5aR & C5a anaphylatoxin & Decreased neutrophil extravasation in the brain. & Sewell et al., 2004 [67] \\
\hline
\end{tabular}

See text for details and explanations. 
and clinical studies have revealed elevated levels of complement components and complement activation fragments in serum, cerebrospinal fluid (CSF), and brain parenchyma after head injury $[12,23,60,61]$. Intracerebral complement deposition after TBI derives either from an altered permeability of a dysfunctional blood-brain barrier (BBB), or from posttraumatic biosynthesis of complement components by resident and infiltrating cells of the central nervous system (CNS) [12,62-64]. Most studies have focused on the central complement component $\mathrm{C} 3$, and on the potential neuroprotective effects of inhibiting $\mathrm{C} 3$ convertases, the level at which the three main activation pathways merge, thus inhibiting downstream complement activation. Clinical studies revealed elevated C3 levels in the CSF of patients with severe TBI [65]. Experimental brain injury models described intracerebral PMNL infiltration and concomitant accumulation of complement C3 in cortical and hippocampal brain sections after experimental TBI in rats [66]. In those studies, C3 accumulation was significantly related to places of intracerebral cell death and to increased intracerebral myeloperoxidase activity [66]. In accordance with these findings, C3-deficient mice were found to have lower neutrophil extravasation and cerebral lesion volumes in a freeze model of brain injury [67]. In light of the central role of C3 and downstream complement activation fragments in the pathophysiology of TBI, much emphasis has been recently devoted to elucidating therapeutic aspects of C3 convertase inhibition, in various experimental model systems [68-72]. Genetically engineered mice, either deficient in the $\mathrm{C} 3$ gene, or with transgenic CNS-restricted overexpression of Crry - a soluble inhibitor of C3 convertases in mice-showed a significant extent of neuroprotection after brain injury, compared to wild-type animals $[67,70]$. The GFAP-sCrry transgenic mice showed a significantly improved neurological outcome and an attenuated extent of posttraumatic $\mathrm{BBB}$ dysfunction in a model of closed head injury [70]. Based on these insights, the concept of Crry-mediated neuroprotection was extrapolated to a pharmacological approach, by posttraumatic injection of a recombinant chimeric Crry-Ig molecule in the same model of closed head injury [71]. The systemic injection of Crry-Ig during an early therapeutic "window of opportunity" within one hour to 24 hours after trauma resulted in a significant neurological improvement and reduced extent of neuronal cell death, compared to vehicle-injected control mice [71]. A similar therapeutic approach was tested in a fluid percussion model of brain injury, using recombinant Vaccinia virus complement control protein (VCP), a potent inhibitor of alternative and classical pathway C3 convertases $[69,72]$. In these studies, the intracranial administration of VCP mediated neuroprotective effects related to posttraumatic preservation of spatial memory, as compared to vehicle-injected controls [69,72].
Further therapeutic approaches were designed to more specifically target "key" effector components of complement activation, such as the anaphylatoxin C5a and its receptor (C5aR, CD88) [29,67,73,74]. In addition, more attention was recently devoted to target specific pathways of complement activation exclusively, in order to overcome the potentially deleterious effects of a complete "shut-down" of complement activation at the central C3 level. This notion is based on the fact that complement also mediates neuroprotective effects in the injured brain, as e.g. shown by a dose-dependent protection of glutamate-induced excitotoxicity against neurons by the C3derived proteolytic fragment, anaphylatoxin C3a [75], and by $\mathrm{C} 3 \mathrm{a}$-mediated induction of nerve growth factor (NGF) by microglia [76]. Based on the recent concept of a "dual role" for complement in the pathophysiology of brain injury, by promoting both early neurotoxic and late neuroreparative mechanisms after TBI $[12,77,78]$, the exclusive targeting of selected complement pathways was given more consideration, as opposed to the "pan" inhibition at the C3 convertase level [79-82]. Among these, the targeted inhibition of the alternative pathway has drawn particular attention in recent years $[79,80,83]$. Factor B, the "key" component of the alternative pathway, was previously reported to be significantly elevated in the intrathecal compartment of patients with severe TBI [65]. Experimental studies on factor B-deficient mice $(f B-/-)$, which are devoid of a functional alternative pathway, revealed significant neuroprotection after closed head injury, in conjunction with a decreased extent of posttraumatic complement activation [79]. These positive findings derived from studies in gene knockout mice were extrapolated into a pharmacological approach, using a neutralizing monoclonal anti-factor B antibody (mAb1379) in the same model system [80]. The postinjury injection of mAb1379 led to significantly attenuated extent of complement activation and anaphylatoxin C5a generation, and was associated with an improved neurological recovery and reduced neuronal cell death after experimental closed head injury [80]. These data imply an important role of the alternative complement pathway in contributing to the delayed neuropathology after TBI, and provide strategic opportunities for therapeutic targeting of alternative pathway molecules as a potential future pharmacological strategy.

An additional avenue of research has been focusing on the terminal complement pathway, or "membrane attack" pathway, which results in cellular lysis by the MAC/C5b-9 [51,84,85]. In clinical studies, elevated levels of activated soluble MAC/C5b-9 were detected in the CSF of severely head-injured patients [62]. Moreover, the extent of intrathecal complement activation was associated with secondary cerebral insults in TBI patients, including post-injury $\mathrm{BBB}$ dysfunction 
$[10,62,64]$. Experimental studies have revealed that the intracerebroventricular injection of MAC induced a marked upregulation of adhesion molecule expression and leukocyte infiltration in the subarachnoid space and cerebral parenchyma [84]. In addition, MAC injection into hippocampus evoked seizures and neurocytoxic effects in rats [85]. Local MAC deposition in the injured brain was demonstrated in experimental models [86] and in injured human brains [87]. The complement regulatory molecule CD59 represents the main controlling molecule of MAC formation and an essential protector from neuronal cell injury after complement activation $[51,88]$. Neurons express CD59 constitutively, as a protective mechanism from autologous "innocent bystander" cell lysis after complement activation in the brain $[51,89]$. However, the posttraumatic activation of phosphatidyl-inositol-specific phospholipase C (PI-PLC) after traumatic brain injury renders neurons vulnerable to MAC-mediated lysis by shedding of the glycosyl-phosphatidyl-inositol (GPI)-anchored glycoprotein CD59 from neuronal membranes $[88,90]$. A recent experimental study on closed head injury in mice lacking the gene for $C d 59 a\left(\mathrm{CD}_{\left.59 \mathrm{a}^{-/-}\right)}\right.$revealed increased susceptibility to brain injury in $C D 59 a^{-/-}$mice, compared to wild-type littermates [88]. In fact, head-injured $C D 59 a^{-1-}$ mice showed increased neuronal cell death in tissue sections assessed by TUNEL histochemistry, in conjunction with elevated serum levels of neuron specific enolase (NSE), an indirect marker of neuronal injury [88]. These data corroborate the crucial role of the complement regulatory molecule CD59 in protecting neurons from complement-mediated lysis, and emphasize the impact of the terminal complement pathway in contributing to the pathophysiology of delayed neuronal cell death after TBI.

Until present, there is a lack of specific pharmacological therapy designed to avoid induction of secondary brain injuries and delayed neuronal cell death [91]. There have been some significant advances in the field of therapeutic complement inhibitor development, in recent years $[43,74,92-94]$. While some of these inhibitors have been successfully tested in experimental head injury models (Table 1) $[67,68,71,80]$, the "bench-tobedside" extrapolation to clinical applications in headinjured patients has yet to be accomplished [91].

\section{Chest trauma and acute lung injury}

Severe blunt chest trauma with associated pulmonary contusions is characterized by a robust inflammatory reaction which can result in exacerbated lung injury, acute respiratory distress syndrome (ARDS), multiple organ failure, and death [95-99]. Activation of alveolar macrophages and recruitment of neutrophils into the interstitial and alveolar compartments are followed by the release of an arsenal of proteinases and oxidants causing leakage of the pulmonary microvasculature and destruction of the alveolar epithelium [100-103]. Various experimental models of lung injury could yield important insights into the critical role of complement activation products, particularly anaphylatoxin $\mathrm{C} 5 \mathrm{a}$, in the pathophysiology of trauma-induced lung inflammation and progressive alveolar injury [28,104-106]. Elevated levels of C5a have been described in broncheoalveolar fluid samples from patients with acute lung injury $[28,107,108]$. When C5a was applied intratracheally in rats exposed to an IgG immune complex model, increased intrapulmonary generation of chemokines, accumulation of neutrophils and changes in vascular permeability could be detected [106]. The protective effects of anti-C5a were further corroborated by the observation that the antibody also suppressed release of tumor necrosis factor (TNF) into bronchoalveolar lavage [109]. Furthermore, C5a was shown to be required for TNF-dependent upregulation of intercellular adhesion molecule-1 (ICAM-1), an essential endothelial adhesion molecule required for neutrophil migration [109]. Czermak and colleagues demonstrated that both the in vitro and in vivo blockade of C5a led to significantly reduced production of $\mathrm{CXC}$ and $\mathrm{CC}$ chemokines [110,111].

A proposed model for the current understanding of C5a-mediated inflammatory pathophysiology of acute lung injury is depicted in Figure 2. Anaphylatoxin C5a has been shown to induce the early release of proinflammatory cytokines by alveolar macrophages, such as TNF and interleukin (IL)-1 $\beta$ [104]. Interaction of endothelial adhesion molecules (e.g. ICAM-1) with their corresponding receptors on neutrophils (e.g. CD11b/ CD18) leads to adhesion and transmigration of neutrophils into the alveoli [104]. Furthermore, release of TNF and IL-1 $\beta$ can also function in an autocrine way and activate alveolar macrophages to generate chemokines [112]. Among these, the different chemokines have been shown to further mediate neutrophil infiltration [113]. Activated neutrophils, alveolar macrophages and epithelial cells release reactive oxygen species and proteinases that cause diffuse alveolar and microvascular damage, thus exacerbating acute lung injury [111].

The interaction of C5a with its receptors, C5aR (CD88) and $\mathrm{C} 5 \mathrm{~L} 2$, is crucial for mediating the pulmonary inflammatory response. Bronchial and alveolar epithelial cells have been shown to express the C5aR [114,115]. Mice lacking the C5aR gene showed a decreased extent of pulmonary inflammation, as characterized by attenuated myeloperoxidase production by neutrophils and decreased vascular leakage [116].

Furthermore, the use of a specific C5aR antagonist led to similar attenuation of inflammation signs in immune complex-induced lung injury, indicating the $\mathrm{C} 5 \mathrm{aR}$ as a predominant effector of the C5a-mediated inflammation 


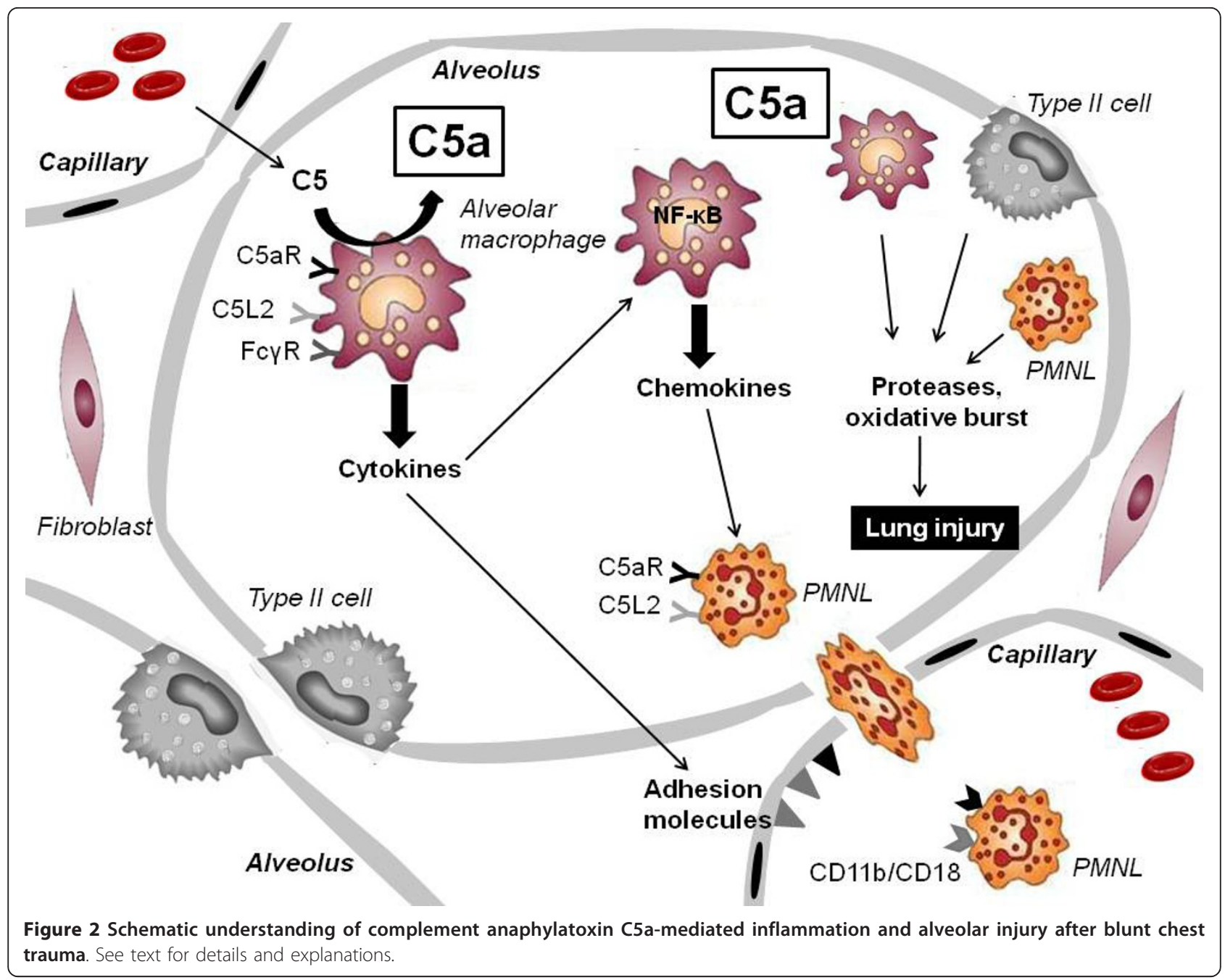

in the lung [117]. A recent study could point out that the cellular responses induced by $\mathrm{C} 5 \mathrm{a} / \mathrm{C} 5 \mathrm{aR}$ interaction are potentiated by a tight connection between complement and Fc $\gamma$ receptors [118]. Both C5aR and Fc $\gamma R$ are known to be expressed on alveolar macrophages [111]. Shushakova et al. found that C5a causes induction of the activating Fc $\gamma$ RIII and suppression of the inhibitory Fc $\gamma$ RII during lung injury resulting in a pro-inflammatory reaction. Genetic ablation of $\mathrm{C} 5 \mathrm{aR}$ expression in mutant mice completely abolished $\mathrm{C} 5 \mathrm{a} / \mathrm{C} 5 \mathrm{aR}$-induced regulation of Fc $\gamma$ Rs and led to decreased intrapulmonary generation of TNF and neutrophil accumulation [118]. Taken together, C5a seems to have a broader critical function through Fc $\gamma \mathrm{R}$ regulation, thus augmenting inflammation in the lung. In contrast to the $\mathrm{C} 5 \mathrm{aR}$, the effects of $\mathrm{C} 5 \mathrm{a}$ are limited by $\mathrm{C} 5 \mathrm{~L} 2$ that is co-expressed with the $\mathrm{C} 5 \mathrm{aR}$ on many cells including neutrophils [119]. Besides of C5a, C5L2 can also bind $\mathrm{C}^{2} \mathrm{a}_{\mathrm{desA} \mathrm{Arg}}$ and potentially additional complement fragments [120]. Gerard et al. could demonstrate a greater influx of inflammatory cells and an enhanced release of IL-6 and TNF in C5L2-deficient mice in the model of immune complex-induced lung injury [121]. This observation proposes an anti-inflammatory role of C5L2 in the lung that seems to counteract $\mathrm{C} 5 \mathrm{a} / \mathrm{C} 5 \mathrm{aR}$-mediated inflammation.

The complement-induced pulmonary response after chest trauma has been suggested to depend on a delicate balance between pro- and anti-inflammatory transcription factors [111]. Alveolar macrophage activation is characterized by increased nuclear translocation of nuclear factor(NF) $-\kappa \mathrm{B}$ and activator protein-1 (AP-1) representing an initial event in the genesis of the inflammatory cascade $[112,122]$. In contrast to NF- $\kappa$ B and AP1 , the transcription factor STAT3 has emerged as a negative regulator of the inflammatory response [28]. Interestingly, C5a has been shown to be responsible for STAT3 activation in lungs and alveolar macrophages after immune complex-induced lung injury whereas no 
complement-dependence could be found for activation of AP-1 [122,123]. STAT3 has been hypothesized to act as a transcriptional mediator for the anti-inflammatory cytokine IL-10, and might contribute to a negative feedback system in acute lung injury $[28,111,124]$. In addition to the above described "classic" lung injury models, a recent study has paid more attention to the immune response after experimental blunt chest trauma induced by a blast wave [104]. Flierl and colleagues reported complement activation after trauma-induced bilateral lung contusion in rats with $\mathrm{C} 5 \mathrm{a}$-dependent perturbations in neutrophil functions. Treatment with anti-C5a antibody abolished functional deficits in neutrophils and reduced intrapulmonary levels of leukocytes and of cytokines [104].

Taken together, there is evidence from various animal models that support a predominant role of $\mathrm{C} 5 \mathrm{a}$ in initiating a cascade of inflammatory events during acute lung injury. If lung trauma is severe, activation of the innate immune system can lead to a dysregulated inflammatory response resulting in ARDS [125]. Elevated levels of $\mathrm{C} 3 \mathrm{a}$ and $\mathrm{C} 5 \mathrm{a}$ were measured in plasma of patients with ARDS [126]. In addition, experimental complement inhibition led to attenuated pathology in an animal model of lung injury [126-128]. Thus, it is tempting to speculate that $\mathrm{C} 5 \mathrm{a}$ might act as a potential target for immunomodulation after chest trauma [74], to avoid the deleterious effects of posttraumatic inflammation, which lead to ARDS, multiorgan failure, and death $[97,129]$.

\section{Musculoskeletal trauma}

Experimental models of musculoskeletal trauma demonstrated that the early posttraumatic inflammatory response is often accompanied by robust generation of complement activation products $[66,104,105]$. However, up to now, the involvement of the complement cascade in bone and cartilage trauma has only been marginally investigated [130]. In recent years, increased attention has been devoted to the investigation of the role of complement in bone biology and fracture healing [131]. Mesenchymal stem cells as progenitor cells of osteoblasts were shown to express the complement receptors $\mathrm{C} 3 \mathrm{aR}$ and $\mathrm{C} 5 \mathrm{aR}$, and the complement regulator molecules, CD55 and CD59 [132-134]. Moreover, osteoblastic differentiation as a key aspect of bone formation and remodeling induces upregulation of a number of complement-related genes, like $\mathrm{C} 1 \mathrm{q}, \mathrm{C} 4, \mathrm{C} 3 \mathrm{aR}$, properdin, C1-inhibitor (C1-INH) and complement factor $\mathrm{H}$ [135]. Pobanz and colleagues reported the expression of a functional C5aR by a human osteoblast-like cell line and detected increased osteoblast IL-6 production after stimulation of these cells with C5a [136]. Furthermore, vitamin D3 has been described to regulate C3 production by murine osteoblastic cells both in vitro and in vivo [137-139]. Complement C3 was postulated to exhibit a modulating influence on the differentiation of bone marrow cells into osteoclasts $[139,140]$. Additional studies pointed out that complement appears to be involved in the transformation of chondral precursors to bone tissue during the enchondral ossification process, involving both the classical and alternative pathway complement activation [141,142]. Consequently, complement components were hypothesized to be also involved in the inflammatory response after musculoskeletal trauma, and in mediating induction of fracture repair processes [131]. A recent study revealed that the C5aR is expressed in fracture callus by differentiated osteoblast, chondroblast-like cells, and osteoclasts [143]. Since fracture healing is known to be delayed in case of additional trauma-induced injuries, it furthermore remains to be examined if systemic complement generation might be the initiator of this delayed recovery after musculoskeletal trauma [144].

In addition to the role in fracture healing, the effect of complement activation on cartilage destruction after joint injuries has been discussed in recent years [130]. Gene expression analyses demonstrated that chondrocytes express a broad range of complement components and complement regulatory proteins [145-147]. The origin of complement components in the synovial fluid remains a topic of debate $[130,148]$. Aside from chondrocyte-induced biosynthesis, it appears that multiple other non-cartilaginous sources contribute to complement release in the inflamed joint, including synovial cells and infiltrating leukocytes [130]. We recently hypothesized that chondrocytes may release pro-inflammatory cytokines, express neoantigens and undergo enhanced apoptosis after cartilage injury [130]. However, until present, the involvement of the complement system in posttraumatic joint inflammation and the development of posttraumatic osteoarthritis remains poorly understood, and requires further research.

The pathophysiology of musculoskeletal trauma and of skeletal muscle ischemia/reperfusion is summarized in Figure 3. The oxygen deficit in major trauma, in conjunction with subsequent reperfusion of ischemic tissues has been recognized as a trigger of an intense inflammatory response that may cause damage both locally in the affected muscle and also in remote organs primary not involved in the ischemic insult [149-152]. Complement activation and consumption represents a critical event in the early phase of limb ischemia/reperfusion (I/R) injury resulting in the release of potent complement fragments like C3a and C5a [150,153,154]. It has been suggested that binding of preexisting natural IgM antibodies to neoantigen expressed by hypoxic cells after interruption of the blood flow is responsible for the 


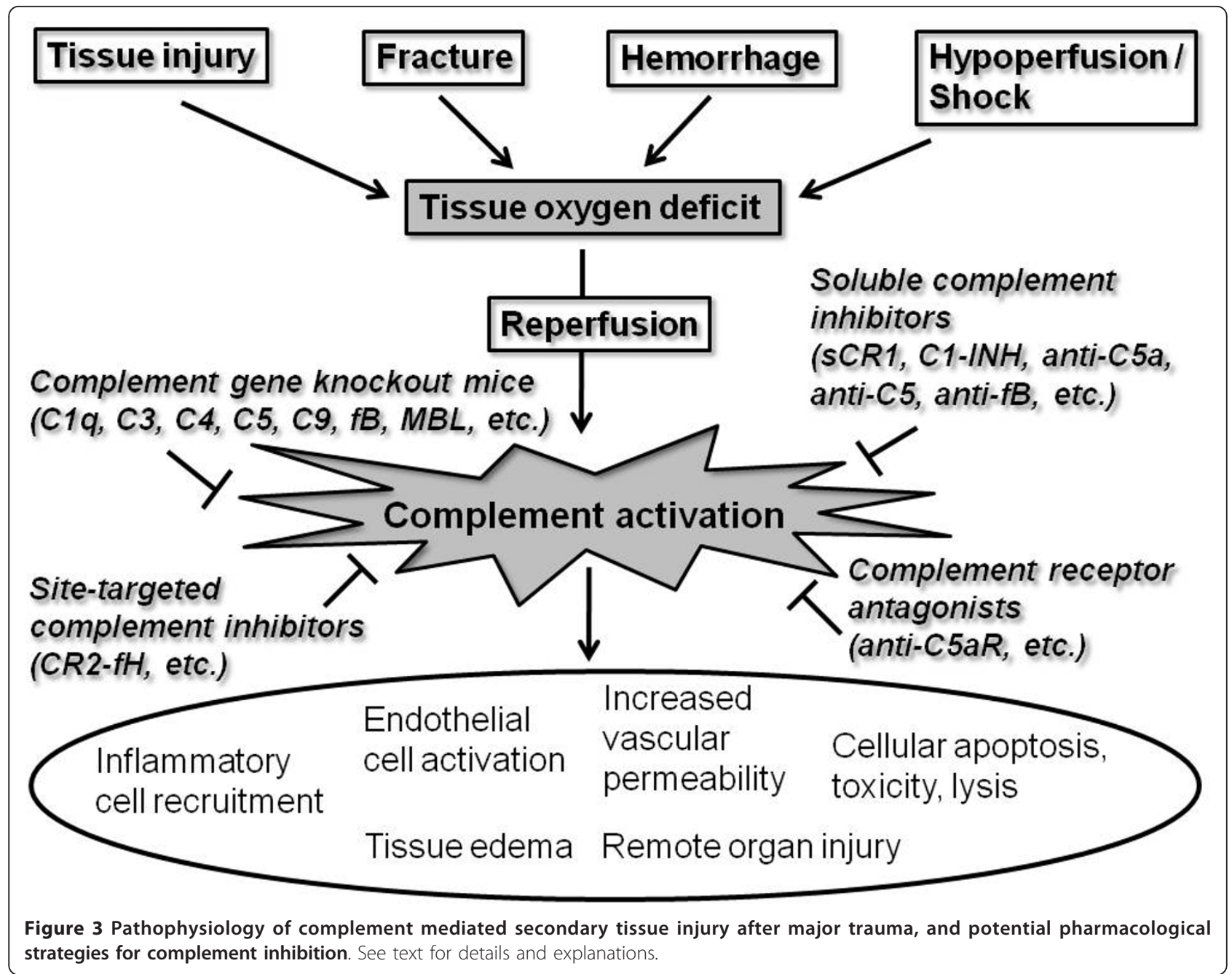

activation of the classical complement pathway that importantly contributes to skeletal muscle I/R injury [155-157]. This hypothesis is strengthened by the fact that mice genetically deficient of mature $\mathrm{B}$ and $\mathrm{T}$ cells and natural antibodies ( $\operatorname{Rag} 1^{-/-}$mice) show significant reductions of tissue damage in a model of hindlimb ischemia and reperfusion $[155,158]$. Furthermore, muscle edema and secondary neutrophil accumulation in the lung, as signs of reperfusion injury, were attenuated in $\mathrm{C}_{1} q^{-/-}$and $\mathrm{C}^{-/-}$mice deficient in central components of the classical complement pathway $[159,160]$. Aside from the classical pathway, recent data indicate important involvement of the classical and the lectin pathway in skeletal muscle I/R injury $[159,161]$. A protective effect was attributed to the complement regulatory molecules decay-accelerating factor (DAF/CD55), C1INH, and soluble complement receptor type 1 (sCR1) after skeletal muscle reperfusion injury [162-164]. Moreover, a pivotal role of $\mathrm{C} 5 \mathrm{a}$ in causing lung damage after hindlimb I/R was shown in an experimental study in rats [165]. In accordance with this observation, multiple markers of local and remote organ injury were markedly reduced in $\mathrm{C5}$-deficient mice, and in mice treated with a neutralizing C5aR antagonist [74,166-168].

In summary, complement activation appears to play a significant role in contributing to post-injury inflammation in musculoskeletal trauma, including fractures, cartilage injury, and skeletal muscle I/R injury.

Polytrauma and sepsis

Polytrauma is characterized as a syndrome of multiple injuries with defined severity which leads to a massive systemic immune activation and to secondary dysfunction and failure of remote, initially uninjured, organs [1,5-7]. Clinical studies have demonstrated that complement activation occurs in plasma of patients after major trauma, as early as at the time of presentation in the emergency department [169-171]. The extent of complement-mediated inflammation was correlated with injury severity, tissue hypoperfusion, and posttraumatic 


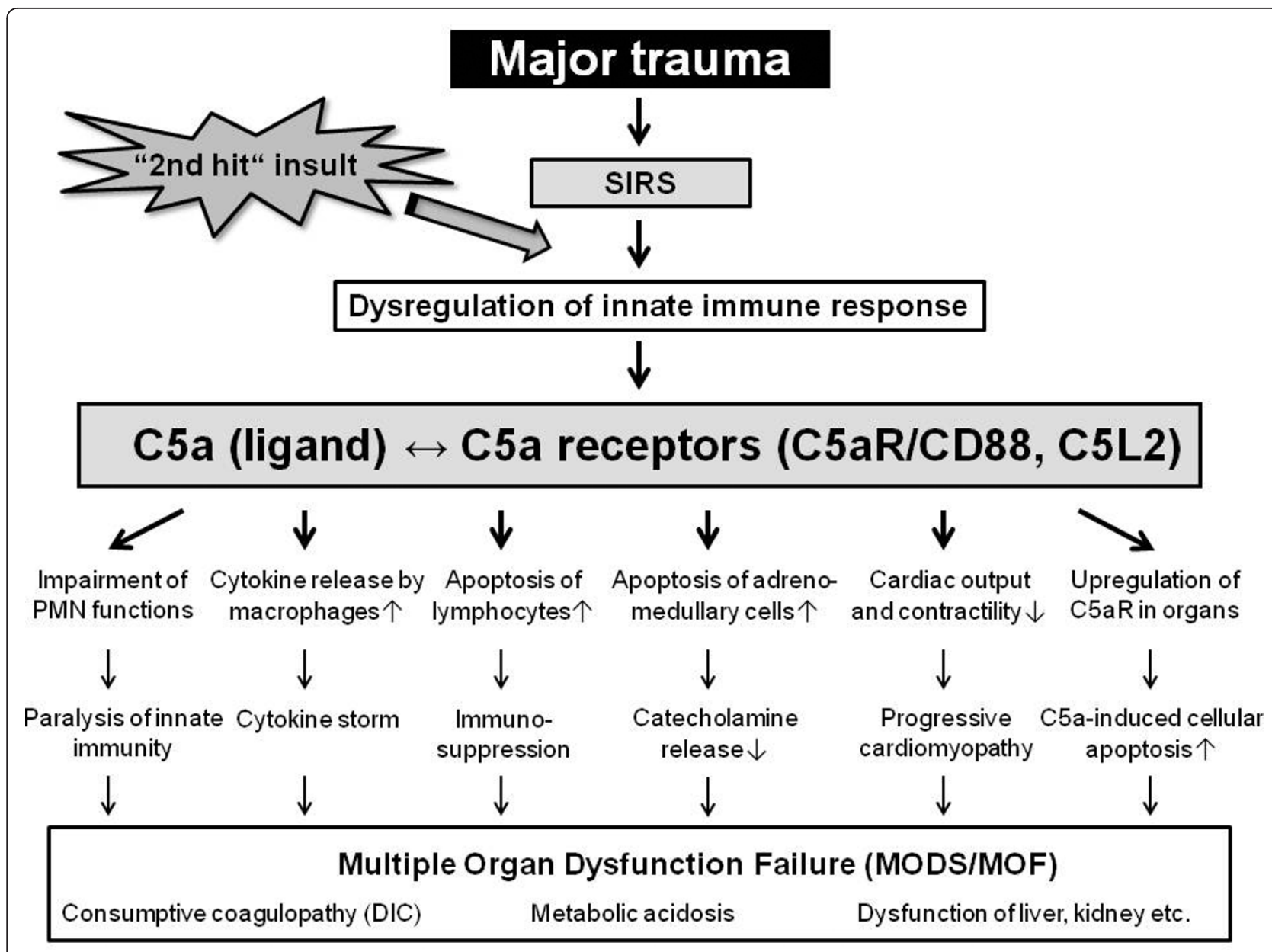

Figure 4 Role of $\mathrm{C} 5$ a ligand and receptor interaction in mediating the detrimental sequelae of major trauma, leading to secondary remote organ failure and adverse outcomes. See text for details and explanations.

mortality [171,172]. Serum levels of C3 and C3a were identified as markers of injury severity and outcome in multiply injured patients $[173,174]$. Moreover, expression profiles of complement regulatory molecules and of the anaphylatoxin C5a receptor (C5aR/CD88) appeared to be significantly altered in leukocytes of multiply injured patients during the early phase of polytrauma, compared to blood samples from healthy volunteers [175]. The expression profiles of CD46 (membrane cofactor protein; MCP), CD59, and C5aR (CD88) on neutrophils correlated inversely with the severity of injury, an observation which was attributed to an intriguing trauma-induced "complementopathy" in multiply injured patients [175].

Sepsis represents a lethal complication of major trauma, characterized by an uncontrolled complement activation, as determined by significantly elevated plasma levels of C3a, C4a and C5a [176-178]. The anaphylatoxin C5a appears to represent the central molecule in the development of the overwhelming inflammatory response in sepsis, and has been coherently described as "too much of a good thing" [179-181] (Figure 4). Blockade of C5a was linked to improved survival in different experimental models of sepsis [182-185]. Persistent elevation of C5a during progressive sepsis was related to a posttraumatic immunparalysis with "shutdown" of crucial neutrophil functions, including a loss of chemotactic and phagocytotic activity, impairment of the oxidative burst, and disturbances in intracellular signaling pathways $[48,186,187]$. Recent studies corroborated an important contribution of C5a in modulating apoptosis in different cell types during sepsis. While apoptosis rates in neutrophils were shown to be significantly attenuated during sepsis, lymphocytes, thymocytes and adrenal medullary cells exhibited increased C5a-dependent susceptibility to programmed cell death [188-192]. The latter phenomenon was hypothesized to be responsible for impaired adreno-medullary catecholamine release predisposing the development of septic shock [191]. Excessive C5a levels during sepsis were furthermore associated with reduced myocardial contractility and 
cardiac output, a phenomenon described as "cardiomyopathy of sepsis" [193]. In general, multiple organs seem to be put at increased risk for C5a-mediated damage induced by an abrupt upregulation of the $\mathrm{C} 5 \mathrm{aR}$ in a variety of tissues (heart, lung, kidney, liver, thymus) in early phases of sepsis $[194,195]$. A recent study implied that C5a-mediated signaling through the two C5a receptors (CD88 and C5L2) contributes to adverse outcome from sepsis [196,197]. In experimental models of sepsis, the blockade of C5a and its receptors has been shown to protect end-organ function and to improve outcomes, thus providing a future new avenue for pharmacological treatment of this detrimental complication of major trauma [198-201]. Future studies will have to be designed to validate this promising notion in a clinical setting.

\section{Conclusions}

In recent years, multiple experimental and clinical studies have substantiated the notion of "key" role of complement activation after major trauma in contributing to the deleterious pathophysiological sequelae in the injured brain, lungs, and musculoskeletal system. Complement activation furthermore significantly contributes to the mechanisms of systemic post-injury complications, such as I/R injury, sepsis, and multiple organ failure. Therapeutic options aimed at attenuating the inflammatory complications of major trauma are currently unsatisfactory, and research strategies have largely failed in extrapolation from "bench to bedside". Experimental data from recent animal studies highlight the potential for complement inhibitors aimed at targeting central complement components and specific complement activation products, as promising future pharmacological agents in patients with major trauma. In this regard, site-targeted complement inhibition by new generation chimeric molecules which link pharmacological inhibitors to the local site of complement activation and tissue deposition may represent the future pharmacological "golden bullet". These chimeric molecules act locally at the site of injury and inflammation, and thus avoid the unwanted negative and adverse effects of a systemic complement blockade. Clearly, there is a tremendous need for well-designed experimental studies to shed some further light into our understanding of the complement-mediated pathology of major trauma, with the hope of designing and implementing new clinical treatment strategies for severely injured patients in the near future.

\section{Author details}

'Department of Orthopaedic Surgery, University of Colorado Denver, School of Medicine, Denver Health Medical Center, 777 Bannock Street, Denver, CO 80204, USA. ²Department of Orthopaedic Trauma, Hand, Plastic, and Reconstructive Surgery, University Hospital UIm, Steinhövelstraße 9, D-89075 Ulm, Germany. ${ }^{3}$ Department of Neurosurgery, University of Colorado Denver, School of Medicine, Denver Health Medical Center, 777 Bannock Street, Denver, CO 80204, USA.

\section{Authors' contributions}

PFS designed the concept of this article. MDN wrote the first draft. All authors contributed to revisions of the manuscript and approved the final version.

\section{Competing interests}

The authors declare that they have no competing interests.

Received: 8 October 2011 Accepted: 30 November 2011 Published: 30 November 2011

\section{References}

1. Stahel PF, Smith WR, Moore EE: Current trends in resuscitation strategy for the multiply injured patient. Injury 2009, 40(Suppl 4):S27-35.

2. Rahimi-Movaghar V, Rasouli MR, Vaccaro AR: Trauma and long-term mortality. JAMA 2011, 305(23):2413-2414, author reply 2413.

3. Cryer C, Fingerhut L, Segui-Gomez M: Injury mortality indicators: recommendations from the International Collaborative Effort on Injury Statistics. Inj Prev 2011, 17(4):281-284.

4. Kauvar DS, Wade CE: The epidemiology and modern management of traumatic hemorrhage: US and international perspectives. Crit Care 2005, 9(Suppl 5):S1-9.

5. Gebhard F, Huber-Lang M: Polytrauma-pathophysiology and management principles. Langenbecks Arch Surg 2008, 393(6):825-831.

6. Keel M, Trentz O: Pathophysiology of polytrauma. Injury 2005, 36(6):691-709

7. Stahel PF, Smith WR, Moore EE: Role of biological modifiers regulating the immune response after trauma. Injury 2007, 38(12):1409-1422.

8. Oikonomopoulou K, Ricklin D, Ward PA, Lambris JD: Interactions between coagulation and complement-their role in inflammation. Semin Immunopathol 2011 .

9. Lippross $S$, Klueter T, Steubesand N, Oestern S, Mentlein R, Hildebrandt F, Podschun R, Pufe T, Seekamp A, Varoga D: Multiple trauma induces serum production of host defence peptides. Injury 2011.

10. Bellander BM, Olafsson IH, Ghatan PH, Bro Skejo HP, Hansson LO, Wanecek M, Svensson MA: Secondary insults following traumatic brain injury enhance complement activation in the human brain and release of the tissue damage marker S100B. Acta Neurochir (Wien) 2011, 153(1):90-100

11. Griffiths M, Neal JW, Gasque P: Innate immunity and protective neuroinflammation: new emphasis on the role of neuroimmune regulatory proteins. Int Rev Neurobiol 2007, 82:29-55.

12. Stahel PF, Morganti-Kossmann MC, Kossmann T: The role of the complement system in traumatic brain injury. Brain Res Brain Res Rev 1998, 27(3):243-256.

13. Dries DJ: Activation of the clotting system and complement after trauma. New Horiz 1996, 4(2):276-288.

14. Hietbrink F, Koenderman L, Rijkers $G$, Leenen L: Trauma: the role of the innate immune system. World J Emerg Surg 2006, 1:15.

15. Bianchi ME, Manfredi AA: Immunology. Dangers in and out. Science 2009, 323(5922):1683-1684.

16. Köhl J: The role of complement in danger sensing and transmission. Immunol Res 2006, 34(2):157-176.

17. Bianchi ME: DAMPs, PAMPs and alarmins: all we need to know about danger. J Leukoc Biol 2007, 81(1):1-5.

18. Carta S, Castellani P, Delfino L, Tassi S, Vene R, Rubartelli A: DAMPs and inflammatory processes: the role of redox in the different outcomes. $J$ Leukoc Biol 2009, 86(3):549-555.

19. Foell D, Wittkowski H, Vogl T, Roth J: S100 proteins expressed in phagocytes: a novel group of damage-associated molecular pattern molecules. J Leukoc Biol 2007, 81(1):28-37.

20. Osterloh A, Geisinger F, Piedavent M, Fleischer B, Brattig N, Breloer M: Heat shock protein 60 (HSP60) stimulates neutrophil effector functions. J Leukoc Biol 2009, 86(2):423-434

21. McGhan $L$, Jaroszewski DE: The role of toll-like receptor-4 in the development of multi-organ failure following traumatic haemorrhagic shock and resuscitation. Injury 2011.

22. Zedler $\mathrm{S}$, Faist $\mathrm{E}$ : The impact of endogenous triggers on traumaassociated inflammation. Curr Opin Crit Care 2006, 12(6):595-601.

23. Stahel PF, Barnum SR: The role of the complement system in CNS inflammatory diseases. Expert Rev Clin Immunol 2006, 2(3):445-456. 
24. Elward K, Gasque P: "Eat me" and "don't eat me" signals govern the innate immune response and tissue repair in the CNS: emphasis on the critical role of the complement system. Mol Immunol 2003, 40(2-4):85-94.

25. Griffiths MR, Gasque P, Neal JW: The regulation of the CNS innate immune response is vital for the restoration of tissue homeostasis (repair) after acute brain injury: a brief review. Int J Inflam 2010, 2010:151097.

26. Griffiths MR, Gasque P, Neal JW: The multiple roles of the innate immune system in the regulation of apoptosis and inflammation in the brain. $J$ Neuropathol Exp Neurol 2009, 68(3):217-226.

27. Alexander JJ, Anderson AJ, Barnum SR, Stevens B, Tenner AJ: The complement cascade: Yin-Yang in neuroinflammation-neuro-protection and -degeneration. J Neurochem 2008, 107(5):1169-1187.

28. Guo RF, Ward PA: Role of C5a in inflammatory responses. Annu Rev Immunol 2005, 23:821-852.

29. Nataf S, Stahel PF, Davoust N, Barnum SR: Complement anaphylatoxin receptors on neurons: new tricks for old receptors? Trends Neurosci 1999, 22(9):397-402.

30. Mastellos D, Morikis D, Isaacs SN, Holland MC, Strey CW, Lambris JD: Complement: structure, functions, evolution, and viral molecular mimicry. Immunol Res 2003, 27(2-3):367-386

31. Klos A, Tenner AJ, Johswich KO, Ager RR, Reis ES, Kohl J: The role of the anaphylatoxins in health and disease. Mol Immunol 2009, 46(14):2753-2766.

32. Ricklin D, Hajishengallis G, Yang K, Lambris JD: Complement: a key system for immune surveillance and homeostasis. Nat Immunol 2010, 11(9):785-797.

33. Kapur MM, Jain P, Gidh M: The effect of trauma on serum C3 activation and its correlation with injury severity score in man. J Trauma 1986, 26(5):464-466

34. Kapur MM, Jain P, Gidh M: Estimation of serum complement and its role in management of trauma. World J Surg 1988, 12(2):211-216.

35. Wink DA, Hines HB, Cheng RY, Switzer CH, Flores-Santana W, Vitek MP, Ridnour LA, Colton CA: Nitric oxide and redox mechanisms in the immune response. J Leukoc Biol 2011, 89(6):873-891.

36. Henrich D, Zimmer S, Seebach C, Frank J, Barker J, Marzi I: Trauma Activated Polymorphonucleated Leukocytes Damage Endothelial Progenitor Cells. Probable Role of CD11b/CD18-CD54 Interaction and Release of Reactive Oxygen Species. Shock 2011.

37. Seitz DH, Perl M, Mangold S, Neddermann A, Braumuller ST, Zhou S, Bachem MG, Huber-Lang MS, Knoferl MW: Pulmonary contusion induces alveolar type 2 epithelial cell apoptosis: role of alveolar macrophages and neutrophils. Shock 2008, 30(5):537-544.

38. Botha AJ, Moore FA, Moore EE, Kim FJ, Banerjee A, Peterson VM: Postinjury neutrophil priming and activation: an early vulnerable window. Surgery 1995, 118(2):358-364, discussion 364-355.

39. Partrick DA, Moore FA, Moore EE, Barnett CC Jr, Silliman CC: Neutrophil priming and activation in the pathogenesis of postinjury multiple organ failure. New Horiz 1996, 4(2):194-210.

40. Morganti-Kossmann MC, Rancan M, Stahel PF, Kossmann T: Inflammatory response in acute traumatic brain injury: a double-edged sword. Curr Opin Crit Care 2002, 8(2):101-105.

41. Zipfel PF: Complement and immune defense: from innate immunity to human diseases. Immunol Lett 2009, 126(1-2):1-7.

42. Mollnes TE, Song WC, Lambris JD: Complement in inflammatory tissue damage and disease. Trends Immunol 2002, 23(2):61-64.

43. Barnum SR: Inhibition of complement as a therapeutic approach in inflammatory central nervous system (CNS) disease. Mol Med 1999, 5(9):569-582.

44. Gasque P: Complement: a unique innate immune sensor for danger signals. Mol Immunol 2004, 41(11):1089-1098.

45. Lambris JD, Reid KB, Volanakis JE: The evolution, structure, biology and pathophysiology of complement. Immunol Today 1999, 20(5):207-211.

46. Monk PN, Scola AM, Madala P, Fairlie DP: Function, structure and therapeutic potential of complement C5a receptors. Br J Pharmacol 2007, 152(4):429-448.

47. Haas PJ, van Strijp J: Anaphylatoxins: their role in bacterial infection and inflammation. Immunol Res 2007, 37(3):161-175.

48. Ward PA: The dark side of C5a in sepsis. Nat Rev Immunol 2004, 4(2):133-142.
49. van Lookeren Campagne M, Wiesmann C, Brown EJ: Macrophage complement receptors and pathogen clearance. Cell Microbiol 2007, 9(9):2095-2102.

50. Mollnes TE, Fosse E: The complement system in trauma-related and ischemic tissue damage: a brief review. Shock 1994, 2(4):301-310.

51. Morgan BP: Regulation of the complement membrane attack pathway. Crit Rev Immunol 1999, 19(3):173-198.

52. Spitzer D, Mitchell LM, Atkinson JP, Hourcade DE: Properdin can initiate complement activation by binding specific target surfaces and providing a platform for de novo convertase assembly. J Immunol 2007, 179(4):2600-2608.

53. Huber-Lang M, Sarma JV, Zetoune FS, Rittirsch D, Neff TA, McGuire SR, Lambris JD, Warner RL, Flierl MA, Hoesel LM, et al: Generation of C5a in the absence of C3: a new complement activation pathway. Nat Med 2006, 12(6):682-687.

54. Amara U, Flierl MA, Rittirsch D, Klos A, Chen H, Acker B, Bruckner UB, Nilsson UB, Gebhard F, Lambris JD, et al: Molecular intercommunication between the complement and coagulation system. J Immunol 2010 185(9):5628-5636.

55. Andriessen TM, Horn J, Franschman G, van der Naalt J, Haitsma I, Jacobs B, Steyerberg EW, VoS PE: Epidemiology, severity classification, and outcome of moderate and severe traumatic brain injury: a prospective multicenter study. J Neurotrauma 2011.

56. Timmons SD: Current trends in neurotrauma care. Crit Care Med 2010, 38(9 Suppl):S431-444.

57. Losiniecki A, Shutter L: Management of traumatic brain injury. Curr Treat Options Neurol 2010, 12(2):142-154.

58. Veerhuis R, Nielsen HM, Tenner AJ: Complement in the brain. Mol Immunol 2011, 48:1592-1603.

59. Longhi L, Perego C, Ortolano F, Zanier ER, Bianchi P, Stocchetti N, Mclntosh TK, MG DS: C1-inhibitor attenuates neurobehavioral deficits and reduces contusion volume after controlled cortical impact brain injury in mice. Crit Care Med 2009, 37(2):659-665.

60. Gasque P, Dean YD, McGreal EP, VanBeek J, Morgan BP: Complement components of the innate immune system in health and disease in the CNS. Immunopharmacology 2000, 49(1-2):171-186.

61. Barnum SR: Complement in central nervous system inflammation. Immunol Res 2002, 26(1-3):7-13.

62. Stahel PF, Morganti-Kossmann MC, Perez D, Redaelli C, Gloor B, Trentz O, Kossmann T: Intrathecal levels of complement-derived soluble membrane attack complex (sC5b-9) correlate with blood-brain barrier dysfunction in patients with traumatic brain injury. J Neurotrauma 2001, 18(8):773-781.

63. Barnum SR: Complement biosynthesis in the central nervous system. Crit Rev Oral Biol Med 1995, 6(2):132-146.

64. Lindsberg PJ, Ohman J, Lehto T, Karajalainen-Lindsberg ML, Paetau A, Wuorimaa T, Carpen O, Kaste M, Meri S: Complement activation in the central nervous system following blood-brain barrier damage in man. Ann Neurol 40:587-596.

65. Kossmann T, Stahel PF, Morganti-Kossmann MC, Jones JL, Barnum SR: Elevated levels of the complement components $C 3$ and factor B in ventricular cerebrospinal fluid of patients with traumatic brain injury. $J$ Neuroimmunol 1997, 73(1-2):63-69.

66. Keeling KL, Hicks RR, Mahesh J, Billings BB, Kotwal GJ: Local neutrophil influx following lateral fluid-percussion brain injury in rats is associated with accumulation of complement activation fragments of the third component (C3) of the complement system. J Neuroimmunol 2000, 105(1):20-30.

67. Sewell DL, Nacewicz B, Liu F, Macvilay S, Erdei A, Lambris JD, Sandor M, Fabry Z: Complement C3 and C5 play critical roles in traumatic brain cryoinjury: blocking effects on neutrophil extravasation by $\mathrm{C} 5 \mathrm{a}$ receptor antagonist. J Neuroimmunol 2004, 155(1-2):55-63.

68. Kaczorowski SL, Schiding JK, Toth CA, Kochanek PM: Effect of soluble complement receptor-1 on neutrophil accumulation after traumatic brain injury in rats. J Cereb Blood Flow Metab 1995, 15(5):860-864.

69. Hicks RR, Keeling KL, Yang MY, Smith SA, Simons AM, Kotwal GJ: Vaccinia virus complement control protein enhances functional recovery after traumatic brain injury. J Neurotrauma 2002, 19(6):705-714.

70. Rancan M, Morganti-Kossmann MC, Barnum SR, Saft S, Schmidt OI, Ertel W Stahel PF: Central nervous system-targeted complement inhibition 
mediates neuroprotection after closed head injury in transgenic mice. $J$ Cereb Blood Flow Metab 2003, 23(9):1070-1074.

71. Leinhase I, Schmidt OI, Thurman JM, Hossini AM, Rozanski M, Taha ME, Scheffler A, John T, Smith WR, Holers VM, et al: Pharmacological complement inhibition at the C3 convertase level promotes neuronal survival, neuroprotective intracerebral gene expression, and neurological outcome after traumatic brain injury. Exp Neurol 2006, 199(2):454-464.

72. Pillay NS, Kellaway LA, Kotwal GJ: Vaccinia virus complement control protein significantly improves sensorimotor function recovery after severe head trauma. Brain Res 2007, 1153:158-165.

73. Stahel PF, Kariya K, Shohami E, Barnum SR, Eugster H, Trentz O, Kossmann T, Morganti-Kossmann MC: Intracerebral complement C5a receptor (CD88) expression is regulated by TNF and lymphotoxin-alpha following closed head injury in mice. J Neuroimmunol 2000, 109(2):164-172.

74. Woodruff TM, Nandakumar KS, Tedesco F: Inhibiting the C5-C5a receptor axis. Mol Immunol 2011, 48(14):1631-1642.

75. van Beek J, Nicole O, Ali C, Ischenko A, MacKenzie ET, Buisson A, Fonatine $\mathrm{M}$ : Complement anaphylatoxin $\mathrm{C} 3 \mathrm{a}$ is selectively neuroprotective against NMDA-induced neuronal cell death. Neuroreport 2001, 12(2):289-293.

76. Heese K, Hock C, Otten U: Inflammatory signals induce neurtrophin expression in human microglial cells. J Neurochem 1998, 70(2):699-707.

77. van Beek J, Elward K, Gasque P: Activation of complement in the central nervous system: roles in neurodegeneration and neuroprotection. Ann $N$ Y Acad Sci 2003, 992:56-71.

78. van Beek J: Complement activation: beneficial and detrimental effects in the CNS. Ernst Schering Res Found Workshop 2004, 47:67-85.

79. Leinhase I, Holers VM, Thurman JM, Harhausen D, Schmidt Ol, Pietzcker M, Taha ME, Rittirsch D, Huber-Lang M, Smith WR, et al: Reduced neuronal cell death after experimental brain injury in mice lacking a functional alternative pathway of complement activation. BMC Neurosci 2006, 7:55.

80. Leinhase I, Rozanski M, Harhausen D, Thurman JM, Schmidt OI, Hossini AM, Taha ME, Rittirsch D, Ward PA, Holers VM, et al: Inhibition of the alternative complement activation pathway in traumatic brain injury by a monoclonal anti-factor B antibody: a randomized placebo-controlled study in mice. J Neuroinflammation 2007, 4:13.

81. You Z, Yang J, Takahashi K, Yager PH, Kim HH, Qin T, Stahl GL, Ezekowitz RA, Carroll MC, Whalen MJ: Reduced tissue damage and improved recovery of motor function after traumatic brain injury in mice deficient in complement component C4. I Cereb Blood Flow Metab 2007, 27(12):1954-1964.

82. Yager PH, You Z, Qin T, Kim HH, Takanashi K, Ezekowitz AB, Stahl GL, Carroll MC, Whalen MJ: Mannose binding lectin gene deficiency increases susceptibility to traumatic brain injury in mice. J Cereb Blood Flow Metab 2008, 28(5):1030-1039.

83. Holers VM, Thurman JM: The alternative pathway of complement in disease: opportunities for therapeutic targeting. Mol Immunol 2004, 41:147-152.

84. Casarsa C, De Luigi A, Pausa M, De Simoni MG, Tedesco F: Intracerebroventricular injection of the terminal complement complex causes inflammatory reaction in the rat brain. Eur J Immunol 2003, 33(5):1260-1270.

85. Xiong ZQ, Qian W, Suzuki K, McNamara JO: Formation of complement membrane attack complex in mammalian cerebral cortex evokes seizures and neurodegeneration. J Neurosci 2003, 23(3):955-960.

86. Bellander BM, von Holst H, Fredman P, Svensson M: Activation of the complement cascade and increase of clusterin in the brain following a cortical contusion in the adult rat. J Neurosurg 1996, 85(3):468-475.

87. Bellander BM, Singhrao SK, Ohlsson M, Mattsson P, Svensson M: Complement activation in the human brain after traumatic head injury J Neurotrauma 2001, 18(12):1295-1311.

88. Stahel PF, Flierl MA, Morgan BP, Persigehl I, Stoll C, Conrad C, Touban BM, Smith WR, Beauchamp K, Schmidt Ol, et al: Absence of the complement regulatory molecule CD59a leads to exacerbated neuropathology after traumatic brain injury in mice. J Neuroinflammation 2009, 6:2.

89. Singhrao SK, Neal JW, Rushmere NK, Morgan BP, Gasque P: Differential expression of individual complement regulators in the brain and choroid plexus. Lab Invest 1999, 79(10):1247-1259.

90. Wei EP, Lamb RG, Kontos HA: Increased phospholipase $\mathrm{C}$ activity after experimental brain injury. J Neurosurg 1982, 56(5):695-698.
91. Beauchamp K, Mutlak H, Smith WR, Shohami E, Stahel PF: Pharmacology of traumatic brain injury: where is the "golden bullet"? Mol Med 2008, 14(11-12):731-740

92. Morgan BP, Harris CL: Complement therapeutics; history and current progress. Mol Immunol 2003, 40(2-4):159-170.

93. Harris CL, Fraser DA, Morgan BP: Tailoring anti-complement therapeutics. Biochem Soc Trans 2002, 30(Pt 6):1019-1026.

94. Qu H, Ricklin D, Lambris JD: Recent developments in low molecular weight complement inhibitors. Mol Immunol 2009, 47(2-3):185-195.

95. Dewar D, Moore FA, Moore EE, Balogh Z: Postinjury multiple organ failure. Injury 2009, 40(9):912-918.

96. Ciesla DJ, Moore EE, Johnson JL, Burch JM, Cothren CC, Sauaia A: The role of the lung in postinjury multiple organ failure. Surgery 2005, 138(4):749-757, discussion 757-748.

97. Moore EE, Moore FA, Harken AH, Johnson JL, Ciesla D, Banerjee A: The two-event construct of postinjury multiple organ failure. Shock 2005, 24(Suppl 1):71-74.

98. Offner PJ, Moore EE: Lung injury severity scoring in the era of lung protective mechanical ventilation: the PaO2/FIO2 ratio. J Trauma 2003, 55(2):285-289.

99. Stahel PF, Schneider P, Buhr HJ, Kruschewski M: [Emergency management of thoracic trauma]. Orthopade 2005, 34(9):865-879.

100. Seitz DH, Palmer A, Niesler U, Froba JS, Heidemann V, Rittlinger A, Braumuller ST, Zhou S, Gebhard F, Knofer MW: Alveolar Macrophage Phagocytosis is Enhanced After Blunt Chest Trauma and Alters the Posttraumatic Mediator Release. Shock 2011.

101. Liener UC, Perl M, Huber-Lang MS, Seitz DH, Brückner UB, Gebhard F, Knöferl MW: Is the function of alveolar macrophages altered following blunt chest trauma? Langenbecks Arch Surg 2011, 396(2):251-259.

102. Visser T, Hietbrink F, Groeneveld KM, Koenderman L, Leenen LP: Isolated blunt chest injury leads to transient activation of circulating neutrophils. Eur J Trauma Emerg Surg 2011, 37(2):177-184.

103. Seitz DH, Niesler U, Palmer A, Sulger M, Braumuller ST, Perl M, Gebhard F, Knoferl MW: Blunt chest trauma induces mediator-dependent monocyte migration to the lung. Crit Care Med 2010, 38(9):1852-1859.

104. Flierl MA, Perl M, Rittirsch D, Bartl C, Schreiber H, Fleig V, Schlaf G, Liener U, Brueckner UB, Gebhard F, et al: The role of C5a in the innate immune response after experimental blunt chest trauma. Shock 2008, 29(1):25-31.

105. Ward PA: Rous-Whipple Award Lecture. Role of complement in lung inflammatory injury. Am J Pathol 1996, 149(4):1081-1086.

106. Czermak BJ, Lentsch AB, Bless NM, Schmal H, Friedl HP, Ward PA: Synergistic enhancement of chemokine generation and lung injury by C5a or the membrane attack complex of complement. Am J Pathol 1999, 154(5):1513-1524.

107. Ishii Y, Kobayashi J, Kitamura S: Chemotactic factor generation and cell accumulation in acute lung injury induced by endotracheal acid instillation. Prostaglandins Leukot Essent Fatty Acids 1989, 37(1):65-70.

108. Kazmierowski JA, Gallin Jl, Reynolds HY: Mechanism for the inflammatory response in primate lungs. Demonstration and partial characterization of an alveolar macrophage-derived chemotactic factor with preferential activity for polymorphonuclear leukocytes. J Clin Invest 1977, 59(2):273-281.

109. Mulligan MS, Schmid E, Beck-Schimmer B, Till GO, Friedl HP, Brauer RB, Hugli TE, Miyasaka M, Warner RL, Johnson KJ, et al: Requirement and role of C5a in acute lung inflammatory injury in rats. J Clin Invest 1996, 98(2):503-512

110. Czermak BJ, Sarma V, Bless NM, Schmal H, Friedl HP, Ward PA: In vitro and in vivo dependency of chemokine generation on C5a and TNF-alpha. J Immunol 1999, 162(4):2321-2325.

111. Gao H, Neff T, Ward PA: Regulation of lung inflammation in the model of IgG immune-complex injury. Annu Rev Pathol 2006, 1:215-242.

112. Lentsch AB, Czermak BJ, Bless NM, Ward PA: NF-kappaB activation during IgG immune complex-induced lung injury: requirements for TNF-alpha and IL-1 beta but not complement. Am J Pathol 1998, 152(5):1327-1336.

113. Czermak BJ, Lentsch AB, Bless NM, Schmal H, Friedl HP, Ward PA: Role of complement in in vitro and in vivo lung inflammatory reactions. J Leukoc Biol 1998, 64(1):40-48.

114. Drouin SM, Kildsgaard J, Haviland J, Zabner J, Jia HP, McCray PB Jr, Tack BF, Wetsel RA: Expression of the complement anaphylatoxin C3a and C5a receptors on bronchial epithelial and smooth muscle cells in models of sepsis and asthma. J Immunol 2001, 166(3):2025-2032. 
115. Riedemann NC, Guo RF, Sarma VJ, Laudes IJ, Huber-Lang M, Warner RL, Albrecht EA, Speyer CL, Ward PA: Expression and function of the C5a receptor in rat alveolar epithelial cells. J Immunol 2002, 168(4):1919-1925.

116. Bozic CR, Lu B, Hopken UE, Gerard C, Gerard NP: Neurogenic amplification of immune complex inflammation. Science 1996, 273(5282):1722-1725.

117. Heller T, Hennecke M, Baumann U, Gessner JE, zu Vilsendorf AM, Baensch M, Boulay F, Kola A, Klos A, Bautsch W, et al: Selection of a C5a receptor antagonist from phage libraries attenuating the inflammatory response in immune complex disease and ischemia/reperfusion injury. $J$ Immunol 1999, 163(2):985-994.

118. Shushakova N, Skokowa J, Schulman J, Baumann U, Zwirner J, Schmidt RE Gessner JE: C5a anaphylatoxin is a major regulator of activating versus inhibitory FcgammaRs in immune complex-induced lung disease. J Clin Invest 2002, 110(12):1823-1830.

119. Ohno M, Hirata T, Enomoto M, Araki T, Ishimaru H, Takahashi TA: A putative chemoattractant receptor, $C 5 \mathrm{~L} 2$, is expressed in granulocyte and immature dendritic cells, but not in mature dendritic cells. Mol Immunol 2000, 37(8):407-412.

120. Cain SA, Monk PN: The orphan receptor C5L2 has high affinity binding sites for complement fragments $\mathrm{C} 5 \mathrm{a}$ and $\mathrm{C} 5 \mathrm{a}$ des-Arg(74). J Biol Chem 2002, 277(9):7165-7169.

121. Gerard NP, Lu B, Liu P, Craig S, Fujiwara Y, Okinaga S, Gerard C: An antiinflammatory function for the complement anaphylatoxin C5a-binding protein, C5L2. J Biol Chem 2005, 280(48):39677-39680.

122. Guo RF, Lentsch AB, Sarma JV, Sun L, Riedemann NC, McClintock SD, McGuire SR, Van Rooijen N, Ward PA: Activator protein-1 activation in acute lung injury. Am J Pathol 2002, 161(1):275-282.

123. Gao H, Guo RF, Speyer CL, Reuben J, Neff TA, Hoesel LM, Riedemann NC, McClintock SD, Sarma JV, Van Rooijen N, et al: Stat3 activation in acute lung injury. J Immunol 2004, 172(12):7703-7712.

124. Tang H, Yan C, Cao J, Sarma JV, Haura EB, Wu M, Gao H: An essential role for Stat3 in regulating IgG immune complex-induced pulmonary inflammation. FASEB J 2011.

125. Ware LB, Matthay MA: The acute respiratory distress syndrome. N Engl J Med 2000, 342(18):1334-1349

126. Hammerschmidt DE, Weaver LJ, Hudson LD, Craddock PR, Jacob HS Association of complement activation and elevated plasma-C5a with adult respiratory distress syndrome. Pathophysiological relevance and possible prognostic value. Lancet 1980, 1(8175):947-949.

127. Weigelt JA, Chenoweth DE, Borman KR, Norcross JF: Complement and the severity of pulmonary failure. J Trauma 1988, 28(7):1013-1019.

128. Proctor LM, Strachan AJ, Woodruff TM, Mahadevan IB, Williams HM, Shiels IA, Taylor SM: Complement inhibitors selectively attenuate injury following administration of cobra venom factor to rats. Int Immunopharmacol 2006, 6(8):1224-1232

129. Moore FA, Moore EE: Evolving concepts in the pathogenesis of postinjury multiple organ failure. Surg Clin North Am 1995, 75(2):257-277.

130. John T, Stahel PF, Morgan SJ, Schulze-Tanzil G: Impact of the complement cascade on posttraumatic cartilage inflammation and degradation. Histol Histopathol 2007, 22(7):781-790.

131. Ehrnthaller C, Ignatius A, Gebhard F, Huber-Lang M: New Insights of an Old Defense System: Structure, Function, and Clinical Relevance of the Complement System. Mol Med 2011, 17(3-4):317-329.

132. Schraufstatter IU, Discipio RG, Zhao M, Khaldoyanidi SK: C3a and C5a are chemotactic factors for human mesenchymal stem cells, which cause prolonged ERK1/2 phosphorylation. J Immuno/ 2009, 182(6):3827-3836.

133. Colter DC, Sekiya I, Prockop DJ: Identification of a subpopulation of rapidly self-renewing and multipotential adult stem cells in colonies of human marrow stromal cells. Proc Natl Acad Sci USA 2001, 98(14):7841-7845.

134. Tian X, Fu R, Deng L: [Method and conditions of isolation and proliferation of multipotent mesenchymal stem cells]. Zhongguo Xiu Fu Chong Jian Wai Ke Za Zhi 2007, 21(1):81-85.

135. Roman-Roman S, Garcia T, Jackson A, Theilhaber J, Rawadi G, Connolly T, Spinella-Jaegle S, Kawai S, Courtois B, Bushnell S, et al: Identification of genes regulated during osteoblastic differentiation by genome-wide expression analysis of mouse calvaria primary osteoblasts in vitro. Bone 2003, 32(5):474-482.

136. Pobanz JM, Reinhardt RA, Koka S, Sanderson SD: C5a modulation of interleukin-1 beta-induced interleukin- 6 production by human osteoblast-like cells. J Periodontal Res 2000, 35(3):137-145.
137. Hong $\mathrm{MH}$, Jin $\mathrm{CH}$, Sato $\mathrm{T}$, Ishimi $\mathrm{Y}$, Abe E, Suda T: Transcriptional regulation of the production of the third component of complement (C3) by 1 alpha, 25-dihydroxyvitamin D3 in mouse marrow-derived stromal cells (ST2) and primary osteoblastic cells. Endocrinology 1991, 129(5):2774-2779.

138. Jin $\mathrm{CH}$, Shinki T, Hong MH, Sato T, Yamaguchi A, Ikeda T, Yoshiki S, Abe E, Suda T: 1 alpha, 25-dihydroxyvitamin D3 regulates in vivo production of the third component of complement (C3) in bone. Endocrinology 1992, 131(5):2468-2475.

139. Sato $T$, Hong $M H$, Jin $C H$, Ishimi $Y$, Udagawa $N$, Shinki T, Abe E, Suda T: The specific production of the third component of complement by osteoblastic cells treated with 1 alpha, 25-dihydroxyvitamin D3. FEBS Lett 1991, 285(1):21-24

140. Mangham DC, Scoones DJ, Drayson MT: Complement and the recruitment of mononuclear osteoclasts. J Clin Pathol 1993, 46(6):517-521.

141. Andrades JA, Nimni ME, Becerra J, Eisenstein R, Davis M, Sorgente N: Complement proteins are present in developing endochondral bone and may mediate cartilage cell death and vascularization. Exp Cell Res 1996, 227(2):208-213.

142. Sakiyama H, Nakagawa K, Kuriiwa K, Imai K, Okada Y, Tsuchida T, Moriya H, Imajoh-Ohmi S: Complement Cls, a classical enzyme with novel functions at the endochondral ossification center: immunohistochemical staining of activated Cls with a neoantigen-specific antibody. Cell Tissue Res 1997, 288(3):557-565.

143. Ignatius $A$, Ehrnthaller $C$, Brenner RE, Kreja L, Schoengraf $P$, Lisson $P$, Blakytny R, Recknagel S, Claes L, Gebhard F, et al: The Anaphylatoxin Receptor $\mathrm{C} 5 \mathrm{aR}$ Is Present During Fracture Healing in Rats and Mediates Osteoblast Migration In Vitro. J Trauma 2011.

144. Bhandari M, Tornetta P, Sprague S, Najibi S, Petrisor B, Griffith L, Guyatt GH: Predictors of reoperation following operative management of fractures of the tibial shaft. J Orthop Trauma 2003, 17(5):353-361.

145. Bradley K, North J, Saunders D, Schwaeble W, Jeziorska M, Woolley DE, Whaley K: Synthesis of classical pathway complement components by chondrocytes. Immunology 1996, 88(4):648-656.

146. Nakagawa K, Sakiyama H, Tsuchida T, Yamaguchi K, Toyoguchi T, Masuda R, Moriya $\mathrm{H}$ : Complement $\mathrm{C} 1 \mathrm{~s}$ activation in degenerating articular cartilage of rheumatoid arthritis patients: immunohistochemical studies with an active form specific antibody. Ann Rheum Dis 1999, 58(3):175-181.

147. Hyc A, Osiecka-Iwan A, Strzelczyk P, Moskalewski S: Effect of IL-1beta, TNFalpha and IL-4 on complement regulatory protein mRNA expression in human articular chondrocytes. Int J Mol Med 2003, 11(1):91-94.

148. Vetto AA, Mannik M, Zatarain-Rios E, Wener MH: Immune deposits in articular cartilage of patients with rheumatoid arthritis have a granular pattern not seen in osteoarthritis. Rheumatol Int 1990, 10(1):13-19.

149. Hart ML, Walsh MC, Stahl GL: Initiation of complement activation following oxidative stress. In vitro and in vivo observations. $\mathrm{Mol} / \mathrm{mmunol}$ 2004, 41(2-3):165-171.

150. Arumugam TV, Magnus T, Woodruff TM, Proctor LM, Shiels IA, Taylor SM: Complement mediators in ischemia-reperfusion injury. Clin Chim Acta 2006, 374(1-2):33-45.

151. Gillani S, Cao J, Suzuki T, Hak DJ: The effect of ischemia reperfusion injury on skeletal muscle. Injury 2011

152. Stahel PF, Smith WR, Moore EE: Hypoxia and hypotension, the "lethal duo" in traumatic brain injury: implications for prehospital care. Intensive Care Med 2008, 34(3):402-404.

153. Heideman M, Norder-Hansson B, Bengtson A, Mollnes TE: Terminal complement complexes and anaphylatoxins in septic and ischemic patients. Arch Surg 1988, 123(2):188-192.

154. Collard CD, Lekowski R, Jordan JE, Agah A, Stahl GL: Complement activation following oxidative stress. Mol Immunol 1999, 36(1314):941-948.

155. Chan RK, Ding G, Verna N, Ibrahim S, Oakes S, Austen WG Jr, Hechtman HB, Moore FD Jr: IgM binding to injured tissue precedes complement activation during skeletal muscle ischemia-reperfusion. J Surg Res 2004, 122(1):29-35.

156. Holers VM, Kulik L: Complement receptor 2, natural antibodies and innate immunity: Inter-relationships in B cell selection and activation. $\mathrm{Mol}$ Immunol 2007, 44(1-3):64-72

157. Diepenhorst GM, van Gulik TM, Hack CE: Complement-mediated ischemiareperfusion injury: lessons learned from animal and clinical studies. Ann Surg 2009, 249(6):889-899. 
158. Austen WG Jr, Zhang M, Chan R, Friend D, Hechtman HB, Carroll MC, Moore FD Jr: Murine hindlimb reperfusion injury can be initiated by a self-reactive monoclonal IgM. Surgery 2004, 136(2):401-406.

159. Chan RK, Ibrahim SI, Takahashi K, Kwon E, McCormack M, Ezekowitz A, Carroll MC, Moore FD Jr, Austen WG Jr: The differing roles of the classical and mannose-binding lectin complement pathways in the events following skeletal muscle ischemia-reperfusion. J Immunol 2006, 177(11):8080-8085.

160. Weiser MR, Williams JP, Moore FD Jr, Kobzik L, Ma M, Hechtman HB, Carroll MC: Reperfusion injury of ischemic skeletal muscle is mediated by natural antibody and complement. J Exp Med 1996, 183(5):2343-2348.

161. Beinrohr L, Dobo J, Zavodszky P, Gal P: C1, MBL-MASPs and C1-inhibitor: novel approaches for targeting complement-mediated inflammation. Trends Mol Med 2008, 14(12):511-521.

162. Toomayan GA, Chen LE, Jiang HX, Qi WN, Seaber AV, Frank MM, Urbaniak JR: C1-esterase inhibitor and a novel peptide inhibitor improve contractile function in reperfused skeletal muscle. Microsurgery 2003, 23(6):561-567.

163. Kyriakides C, Wang Y, Austen WG Jr, Favuzza J, Kobzik L, Moore FD Jr, Hechtman HB: Moderation of skeletal muscle reperfusion injury by a sLe (x)-glycosylated complement inhibitory protein. Am J Physiol Cell Physiol 2001, 281(1):C224-230.

164. Weeks C, Moratz C, Zacharia A, Stracener C, Egan R, Peckham R, Moore FD Jr, Tsokos GC: Decay-accelerating factor attenuates remote ischemia-reperfusion-initiated organ damage. Clin Immunol 2007, 124(3):311-327.

165. Bless NM, Warner RL, Padgaonkar VA, Lentsch AB, Czermak BJ, Schmal H, Friedl HP, Ward PA: Roles for C-X-C chemokines and C5a in lung injury after hindlimb ischemia-reperfusion. Am J Physiol 1999, 276(1 Pt 1):L57-63.

166. Woodruff TM, Arumugam TV, Shiels IA, Reid RC, Fairlie DP, Taylor SM: Protective effects of a potent $\mathrm{C} 5 \mathrm{a}$ receptor antagonist on experimental acute limb ischemia-reperfusion in rats. J Surg Res 2004, 116(1):81-90.

167. Kyriakides C, Austen WG Jr, Wang Y, Favuzza J, Moore FD Jr, Hechtman HB: Neutrophil mediated remote organ injury after lower torso ischemia and reperfusion is selectin and complement dependent. J Trauma 2000, 48(1):32-38.

168. Kyriakides C, Austen W Jr, Wang Y, Favuzza J, Kobzik L, Moore FD Jr, Hechtman HB: Skeletal muscle reperfusion injury is mediated by neutrophils and the complement membrane attack complex. Am J Physiol 1999, 277(6 Pt 1):C1263-1268.

169. Fosse E, Pillgram-Larsen J, Svennevig JL, Nordby C, Skulberg A, Mollnes TE, Abdelnoor $\mathrm{M}$ : Complement activation in injured patients occurs immediately and is dependent on the severity of the trauma. Injury 1998, 29(7):509-514.

170. Roumen RM, Redl H, Schlag G, Zilow G, Sandtner W, Koller W, Hendriks T, Goris RJ: Inflammatory mediators in relation to the development of multiple organ failure in patients after severe blunt trauma. Crit Care Med 1995, 23(3):474-480.

171. Ganter MT, Brohi K, Cohen MJ, Shaffer LA, Walsh MC, Stahl GL, Pittet JF: Role of the alternative pathway in the early complement activation following major trauma. Shock 2007, 28(1):29-34.

172. Nuytinck JK, Goris JA, Redl H, Schlag G, van Munster PJ: Posttraumatic complications and inflammatory mediators. Arch Surg 1986, 121(8):886-890.

173. Hecke F, Schmidt U, Kola A, Bautsch W, Klos A, Kohl J: Circulating complement proteins in multiple trauma patients-correlation with injury severity, development of sepsis, and outcome. Crit Care Med 1997, 25(12):2015-2024

174. Sharma DK, Sarda AK, Bhalla SA, Goyal A, Kulshreshta VN: The effect of recent trauma on serum complement activation and serum C3 levels correlated with the injury severity score. Indian J Med Microbiol 2004, 22(3):147-152.

175. Amara U, Kalbitz M, Perl M, Flierl MA, Rittirsch D, Weiss M, Schneider M, Gebhard F, Huber-Lang M: Early expression changes of complement regulatory proteins and $\mathrm{C} 5$ a receptor $(\mathrm{CD} 88)$ on leukocytes after multiple injury in humans. Shock 2010, 33(6):568-575.

176. Bengtson A, Heideman M: Anaphylatoxin formation in sepsis. Arch Surg 1988, 123(5):645-649.

177. Ward PA: Sepsis, apoptosis and complement. Biochem Pharmacol 2008, 76(11):1383-1388.
178. Nakae H, Endo S, Inada K, Takakuwa T, Kasai T, Yoshida M: Serum complement levels and severity of sepsis. Res Commun Chem Pathol Pharmacol 1994, 84(2):189-195.

179. Gerard C: Complement C5a in the sepsis syndrome-too much of a good thing? N Engl J Med 2003, 348(2):167-169.

180. Guo RF, Ward PA: C5a, a therapeutic target in sepsis. Recent Pat Antiinfect Drug Discov 2006, 1(1):57-65.

181. Ward PA: Role of C5 activation products in sepsis. ScientificWorldJournal 2010, 10:2395-2402

182. Stevens JH, O'Hanley P, Shapiro JM, Mihm FG, Satoh PS, Collins JA, Raffin TA: Effects of anti-C5a antibodies on the adult respiratory distress syndrome in septic primates. J Clin Invest 1986, 77(6):1812-1816.

183. Czermak BJ, Sarma V, Pierson CL, Warner RL, Huber-Lang M, Bless NM, Schmal H, Friedl HP, Ward PA: Protective effects of C5a blockade in sepsis. Nat Med 1999, 5(7):788-792.

184. Huber-Lang MS, Sarma JV, McGuire SR, Lu KT, Guo RF, Padgaonkar VA Younkin EM, Laudes IJ, Riedemann NC, Younger JG, et al: Protective effects of anti-C5a peptide antibodies in experimental sepsis. FASEB J 2001, 15(3):568-570.

185. Huber-Lang MS, Riedeman NC, Sarma JV, Younkin EM, McGuire SR, Laudes IJ, Lu KT, Guo RF, Neff TA, Padgaonkar VA, et al: Protection of innate immunity by $\mathrm{C} 5 \mathrm{aR}$ antagonist in septic mice. FASEB J 2002 , 16(12):1567-1574

186. Huber-Lang MS, Younkin EM, Sarma JV, McGuire SR, Lu KT, Guo RF, Padgaonkar VA, Curnutte JT, Erickson R, Ward PA: Complement-induced impairment of innate immunity during sepsis. J Immunol 2002, 169(6):3223-3231.

187. Ward PA, Gao H: Sepsis, complement and the dysregulated inflammatory response. J Cell Mol Med 2009, 13(10):4154-4160.

188. Guo RF, Sun L, Gao H, Shi KX, Rittirsch D, Sarma VJ, Zetoune FS, Ward PA: In vivo regulation of neutrophil apoptosis by C5a during sepsis. J Leukoc Biol 2006, 80(6):1575-1583.

189. Hotchkiss RS, Tinsley KW, Swanson PE, Schmieg RE Jr, Hui JJ, Chang KC, Osborne DF, Freeman BD, Cobb JP, Buchman TG, et al: Sepsis-induced apoptosis causes progressive profound depletion of B and CD4+ T lymphocytes in humans. J Immunol 2001, 166(11):6952-6963.

190. Guo RF, Huber-Lang M, Wang X, Sarma V, Padgaonkar VA, Craig RA, Riedemann NC, McClintock SD, Hlaing T, Shi MM, et al: Protective effects of anti-C5a in sepsis-induced thymocyte apoptosis. J Clin Invest 2000, 106(10):1271-1280.

191. Flierl MA, Rittirsch D, Chen AJ, Nadeau BA, Day DE, Sarma JV, HuberLang MS, Ward PA: The complement anaphylatoxin C5a induces apoptosis in adrenomedullary cells during experimental sepsis. PLoS One 2008, 3(7):e2560

192. Hotchkiss RS, Nicholson DW: Apoptosis and caspases regulate death and inflammation in sepsis. Nat Rev Immunol 2006, 6(11):813-822.

193. Niederbichler AD, Hoesel LM, Westfall MV, Gao H, Ipaktchi KR, Sun L Zetoune FS, Su GL, Arbabi S, Sarma JV, et al: An essential role for complement $\mathrm{C} 5 \mathrm{a}$ in the pathogenesis of septic cardiac dysfunction. $J$ Exp Med 2006, 203(1):53-61.

194. Riedemann NC, Guo RF, Neff TA, Laudes IJ, Keller KA, Sarma VJ, Markiewski MM, Mastellos D, Strey CW, Pierson CL, et al: Increased C5a receptor expression in sepsis. J Clin Invest 2002, 110(1):101-108.

195. Riedemann NC, Guo RF, Laudes IJ, Keller K, Sarma VJ, Padgaonkar V Zetoune FS, Ward PA: C5a receptor and thymocyte apoptosis in sepsis. FASEB J 2002, 16(8):887-888.

196. Rittirsch D, Flierl MA, Nadeau BA, Day DE, Huber-Lang M, Mackay CR, Zetoune FS, Gerard NP, Cianflone K, Kohl J, et al: Functional roles for C5a receptors in sepsis. Nat Med 2008, 14(5):551-557.

197. Huber-Lang M, Sarma JV, Rittirsch D, Schreiber H, Weiss M, Flierl M, Younkin E, Schneider M, Suger-Wiedeck H, Gebhard F, et al: Changes in the novel orphan, $\mathrm{C} 5$ a receptor $(\mathrm{C} 5 \mathrm{~L} 2)$, during experimental sepsis and sepsis in humans. J Immunol 2005, 174(2):1104-1110.

198. Huber-Lang M, Sarma VJ, Lu KT, McGuire SR, Padgaonkar VA, Guo RF, Younkin EM, Kunkel RG, Ding J, Erickson R, et al: Role of C5a in multiorgan failure during sepsis. J Immunol 2001, 166(2):1193-1199.

199. Laudes IJ, Chu JC, Sikranth S, Huber-Lang M, Guo RF, Riedemann N, Sarma JV, Schmaier AH, Ward PA: Anti-c5a ameliorates coagulation/ fibrinolytic protein changes in a rat model of sepsis. Am J Pathol 2002, 160(5):1867-1875. 
200. Flierl MA, Schreiber H, Huber-Lang MS: The role of complement, C5a and its receptors in sepsis and multiorgan dysfunction syndrome. J Invest Surg 2006, 19(4):255-265.

201. Tsukamoto T, Chanthaphavong RS, Pape HC: Current theories on the pathophysiology of multiple organ failure after trauma. Injury 2010, 41(1):21-26.

doi:10.1186/1423-0127-18-90

Cite this article as: Neher et al:: Molecular mechanisms of inflammation and tissue injury after major trauma-is complement the "bad guy"?

Journal of Biomedical Science 2011 18:90.

Submit your next manuscript to BioMed Central and take full advantage of:

- Convenient online submission

- Thorough peer review

- No space constraints or color figure charges

- Immediate publication on acceptance

- Inclusion in PubMed, CAS, Scopus and Google Scholar

- Research which is freely available for redistribution

Submit your manuscript at www.biomedcentral.com/submit
() Biomed Central 